\title{
4 \\ The Myth of Politics \\ in the Jewish Communities of the Italian City-States
}

In 1638, the Venetian rabbi Simone (Simhah) Luzzatto described the Jewish nation as "a nation incapable of any form of political governance while they are in their current state, [and] so preoccupied [...] with their particular predicament that they fail to take any interest in the universal." "A marginal group so completely removed from power and confined to a narrow range of economic activities could hardly concern itself with "the universal." At an intellectual level, this meant that the Jews had difficulty thinking of the political and social reality of their society as a whole-beyond the confines of the Jewish community - and analyzing these concepts. And yet, as we shall see, between the sixteenth and the first half of the seventeenth centuries, a few Italian Jews applied themselves to this task, producing interesting works which attempted to represent the universal from the perspective of the particular.

During that period, the Italian peninsula was a sort of experimental laboratory for new political ideas and practices. For centuries, its strong commercial, industrial, and financial performance, combined with its almost chronic institutional instability and the extreme political fragmentation of its territory, had laid the ground for major breakthroughs in political thought. In this country, Jews could not truly be said to be foreigners, as their presence predated the fall of the kingdom of Judea. Nonetheless, being well-established had not prevented them from remaining marginalized, as Italy had never had more than 50,000 Jews, and their involvement in its public sphere was very limited. Indeed, even during the period of integration, it was inconceivable that the Jews might actively participate in Italian politics.

\section{Yoḥanan Alemanno in Praise of Florence}

The first significant Jewish author to write on political issues was Yohanan Alemanno (ca. 1434-ca.1504). He spent years in the Florence of the Medici, at a time when Lorenzo the Magnificent was in power, taking part in the 
cultural life of the city. He was active in neo-Platonic circles and particularly close to Giovanni Pico della Mirandola. ${ }^{2}$

Yohanan Alemanno remains largely unpublished to this day. However, recent studies by Arthur M. Lesley, Abraham Melamed, Moshe Idel, and Fabrizio Lelli provide a good overview of his works. ${ }^{3}$ Alemanno elaborates on a sort of Jewish version of Florentine neo-Platonism. In his two great works, Hesheq Shelomo ("The Desire of Solomon") and Hay ha-olamym ("The Immortal," or "The Eternal"), he describes the rise of the human soul as it moves through different phases, from worldly concerns to a quasi-mystical fusion with the intellect agent. King Solomon, who excelled at all the sciences and was elevated by his love (or desire, hesheq) for Good-which coincided with intellectual contemplation-epitomizes this process, for Alemanno. However, he views Lorenzo de' Medici as the contemporary embodiment of the figure of the philosopher-king. He describes him as follows:

A man named Lorenzo de' Medici was extracted from the mountain of this land, and he was more precious than gold; with circumspection and a spiritual intelligence that lies beyond the ken of the people, he commands and rules over the surrounding areas to their outermost edges [...] and he does not position himself in the community as someone whose power is founded on force and ostentatious physical power, unlike the other kings, princes and rulers of the world. Rather he governs with discernment and great humility: this is the treasure (otzaro) from which he draws his strength. And everything he wishes for is in the spirit of the knowledge and fear of God. ${ }^{4}$

Alemanno then praises the qualities of the inhabitants of the city, naming seven of them. The impression this creates is of an industrious republic that is able to rule itself, favors the art of discourse over violence, and aspires to unity while overcoming ideological differences, and where one's true thoughts are concealed. But above all it seems to be a city where the practical approach-i.e., political action-is born of speculative knowledge. ${ }^{5}$ This characteristic combination of ideological control and enticement to philosophical speculation evokes Florence under Lorenzo de' Medici's enlightened government.

Alemanno ends his account of each virtue with a reference to his own selfimprovement: "I acquired this quality (...) I strove to adopt this behavior." 
In this respect, he seems to be part of the intellectual life of the city, which encouraged individual spiritual and speculative exploration, even as it hindered open debate and the elaboration of a political and social discourse based on observations of reality. On the other hand, Alemanno does not show interest in the Jewish community as a distinct social entity. King Solomon represents a sort of myth of origins for him, an ideal source of inspiration for the improvement of his Jewish readers and students. Although his works make space for politics in between rhetorical and metaphysical speculations, his thought does not allow for an examination of the role of force in political action. For lack of the conceptual tools that would allow him to understand the actual predicament of the Jews, Alemanno overlooks their marginal and precarious position. Yet, this precariousness was far from exceptional when Lorenzo de' Medici was in power, as Jews were not the only ones to depend on the good will of the republican Prince.

\section{The Project of a "Modern" Jewish Society in the Works of Avraham Portaleone}

A century later, the writings of the Mantuan Jewish physician Avraham Portaleone, outlined a dramatically new relationship to politics. His encyclopedic Shiltey ha-Gibborym (1612) devotes a few interesting pages to politics and the military arts.

Explaining the role priests and Levites played in the service of the Sanctuary, the author mentions the existence of a third group of people, the Israelites, and subdivides them into different classes. Proceeding to describe each one of these classes, Portaleone emphasizes the fact that he is drawing from personal experience:

I am not aware that any other author has described these classes in any detail, except for Maimonides who wrote something [...] about priests. This is why I have decided to provide readers with brief insights which are not drawn from books. ${ }^{6}$

Portaleone explains that there are two main types of Israelites: those who contribute to the well-being of society and those who teach men the ways of the Torah and Mitzwoth (the commandments). 
According to Portaleone, membership in this last subsection has seventeen degrees, ranging from respectable men who devote themselves to studying the sacred texts to prophets. This list is temporally and thematically consistent with the focus of his book on the Sanctuary. However, Portaleone's account of the first type of Israelites - those who represent civil society and the public sphere, whether on a military, administrative, or strictly political level - actually evokes a contemporary nation, and therefore strays from both a historical perspective and the Jewish context. Let us try to explain this anachronism.

When he lists the professions which make up civil society, Portaleone seems particularly drawn to occupations involving ceaseless movement and effort: manual work, but also intellectual labor. He gives a detailed description of the extraction and transformation of minerals and of field work. His evocation of merchants constrained to live peripatetic lives so as to provide for their families is clearly sympathetic. The work of those who deploy scientific knowledge and numerical skills in order to make physical labor more efficient prompts him to coin a phrase inspired from a Biblical saying, be-ze'ath af tevunatam (through the sweat of hard intellectual graft). These short descriptions cannot fail to recall the portrait of sixteenth- and seventeenth-century Italy which Piero Camporesi painted in The Beautiful Lands, which describes:

These cities full of craftsmen and workers, of workshops where resourceful men [...] alter, mold, and translate into the language of usefulness and beauty the stone and metals extracted from caves and mines through the sweat and blood of other laborers. ${ }^{?}$

Portaleone describes sedentary merchants spending their time at home, resting, or trading their goods for money or drafts, and does not even mention brokers and other financial occupations; as a result, he either does not account for the more specifically Jewish professions of the period or discredits them. As for those at the top of the social pyramid-landowners- he describes them in the following terms:

the man of high standing who dwells at his court, under the vine and figtree, partaking of the finest produce of the land with no need for work, he is noble and dignified. ${ }^{8}$ 
This implicit criticism of a particular medieval conception of society also tacitly questions the role it allocates to Jews. Portaleone's sympathy for the manual arts and all activities involving movement suggests that, despite his "conversion" and return to the intense devotion of his fathers' religion, he has not lost the modern sensibility that once led him to choose experience and scientific reasoning over auctoritates. ${ }^{9}$

It is probably worth reminding ourselves that Portaleone's classifications describe a non-existent, and purely imaginary, Jewish society. He takes an exclusivist stance, focusing only on the people of Israel and making everything else revolve around them. This stance may exhibit a wish for what one might call-borrowing from Zionist terminology—the "normalization" of the Jewish condition.

Portaleone's portrait of the military sphere and activities seems to confirm this hypothesis. Versed in science and technology, he was well-acquainted with this field and wished to impart his knowledge to his readers. But how could a digression on the military arts fit in to an essay on the Temple? Portaleone begins by resorting to a familiar strategy, which consists of asserting that the Jewish people and their legislators have a particular claim to this discipline.

Portaleone explains that many learned Gentiles have devoted their whole lives to studying what to do in times of war and peace. In contrast, the Torah effortlessly enlightens the Jews, teaching them "in a second" both what path to take in civilian life (be-darkhey ha- 'olam) and how to avoid evil, idolatrous peoples under the protection of divine Wisdom. One of the first lessons Revelation teaches the Jews is how to deploy troops. When the Romans followed the biblical battle plan, they became unbeatable, as the writings of both Sallust and Titus Livius show. Portaleone reiterates the notion of biblical precedence at the end of the chapter: as well as confirming its significance in his eyes, this leads him to argue that the Jews have a right to debate military matters:

One must remember that our Lord is majestic in holiness, dreadful in praises and works miracles: why couldn't we also debate military matters with justice, measure, and reason? Thus, all those who answer to the name of Israel must realize that God spoke unto us as well; and that we have no need of erudite books on these matters, which are against religious teachings. ${ }^{10}$ 
After a digression regarding the proper deployment of troops, Portaleone proceeds to describe a modern army. In order to place these remarks in a Jewish context, he imagines the priest in charge of a war making a speech which expands on a passage from Deuteronomy, chapter 20. Wavering between biblical and contemporary perspectives, he describes ruthless enemies armed in the modern and ancient fashions. ${ }^{11}$ The Jewish people must prepare for war, Portaleone suggests, because God wills it, even though he could have led the fight Himself. In his speech, the imaginary priest explains:

You too must do your part. Do not gaze at the sky like a dim-witted idler, like a fool counting the stars; so numerous that they cannot be counted [...]. It falls to you, $\mathrm{O}$ blessed by the Lord, to take up arms and kill those who hate you, Ismael, Moab and the converts, to vindicate yourselves from your enemies, who are rising to destroy you. ${ }^{12}$

One may wonder what provoked this rather belligerent tone. Did the predicament of Mantuan Jews - and of Italian Jews, more generally-justify such vindictive feelings? It would be tempting to attribute these pugnacious lines to the creation of the ghetto in Mantua in 1610 and 1611, at the same time as Shiltey ha-Gibborym ${ }^{13}$ was published. Yet Portaleone states that he wrote his book between 1606 and 1607. What is more, recent scholarship suggests that the impact of the creation of the ghettoes on Jewish communities was less severe than was once thought. Could Portaleone's bellicosity be attributed to the fact that Italian society was becoming more entrenched at the turn of the sixteenth century? Much as the Catholic Church redefined its religious and intellectual arenas in the wake of the Council of Trent, Jewish attempts to rethink their own identity led them close to a form of national exclusivism. But this did not keep society as a whole from moving toward a sort of proto-modernity, fostering tensions in religious quarters.

The priest's speech ends as it began, on a combination of modern insights and religious justifications. Envisioning a Jewish "ghost-army" focused almost exclusively on artillery, at the expense of cavalry, he goes so far as to state the number of firearms it should ideally own: 50 canons, 3,000 muskets, and 5,000 "Spanish" harquebuses. Discomforted by the foreign-sounding names of these weapons, Portaleone manages to link them to the biblical qesheth nehushah (the antique bronze ark mentioned in Psalms 18:36 and Job 20:24), which allows him to refer to the musket as qesheth. The extreme 
and almost ideal modernity of this army is obvious: in particular, the focus Portaleone places on its artillery defies contemporary notions on military strategy. Indeed, it anticipates future developments, even if strategists as talented as the Swedish King Gustav Adolph in fact still deployed one lancer for two musketeers twenty years later. ${ }^{14}$

Portaleone finds biblical references in support of his marked preference for artillery: Mosheh explicitly told the Jews (Deuteronomy 17:16) that the king should not multiply the number of his horses, while God reminded Joshua (Joshua 11:6) to burn the horses and chariots of the Cananeans. Thus the cavalry, which was a privileged part of medieval warfare, is rejected in favor of a modernity heralded by the Bible.

Portaleone's concern with biblical justification makes it impossible for him to assess military techniques dispassionately-i.e., solely in light of their usefulness. Instead, he feels compelled to expound on this issue, despite coming from a social background which leaves him completely unfamiliar with military drills. As well as evoking the penitent's characteristic tendency to consider everything in a religious light, this attempt to mark out such a secular sphere as sacred reveals the frustration of a talented man confined to the margins of society, as the following example will illustrate. The detailed account Portaleone gives his readers of the handling of weapons in the book corresponds exactly to an engraving by Jacob de Gheyn on the same question in Maniement d'armes, d'arquebuses, mousquetz et piques (Handling Weapons, Harquebuses, Muskets and Pikes), which was published in Amsterdam in 1608. Although the two authors give exactly the same account of providing individual soldiers with weapons, ${ }^{15}$ there are significant differences in the way they present this process. Portaleone describes it without resorting to illustrations, relying instead on a tale in which past and present overlap. Although he gives detailed descriptions to his readers, he evokes a fictional army and targets an audience which may or may not be familiar with the concepts of war. Moreover, he feels compelled to include in it a religious background which is both extraneous, as evidenced by his depiction of the Temple, and fictitious, as exemplified by the discourse of the Kohen mashuah, the priest who spurs the troops to war. The Dutch author had no such concerns. His illustrations needed no additional justifications: they were merely meant to instruct soldiers and officers in military drill. Moreover, the servicemen themselves and amateur students of weaponry were the expected readers for this type of book. For the same reason, it 
was natural that the Prince of Orange - a politician and military strategistshould back his work. In contrast, Portaleone composed his own Hebrew book with his children or students in mind.

In sum, Portaleone does not appear interested in questions of power; instead, his considerations on society and the military arts are characterized by:

1) a fundamentalist desire to integrate secular concerns into the religious sphere;

2) a tension between the social usefulness of the knowledge Portaleone imparts to his readers and the reality of Jewish social marginality;

3) a belief in the "normalcy" of the Jews, which borrows from the traditional motif of Jewish self-sufficiency and has aggressive undertones.

\section{The Praise of the Venetian Republic}

Among the Italian Jewish intellectuals and Jewish intellectuals who lived in Italy for parts of their lives and wrote about politics, one of the most notable is Yitzhaq Abravanel (1437-1508). This important figure, who was, within the limits of his condition as a Jew, personally invested in political issues as an advisor to princes and governors, transmitted his ideas on the best form of government not in a specific treatise, but in his comments in Hebrew on the Bible. The most "political" of the Jews of the late fifteenth century thus turned to a religious literary genre to express his thought. Furthermore, his ideas refer to biblical history and the Jewish precepts that inspired it, and therefore refer to the realm of the ideal, with little reference to the observation of reality.

The two passages of his commentary on the Torah that are most significant for political doctrine, Deuteronomy 17:8 (which refers to the Jews possibly having a king when they are established in the Promised Land ${ }^{16}$ ) and Exodus 18 (the advice given by Yitro to Moses on how to administer justice ${ }^{17}$ ), demonstrate a certain aversion to monarchical government, and certainly to absolute monarchy.

In Abravanel's view, the king of Israel - and it is on this figure that the Spanish author concentrates his analysis - is primarily subordinated to the Torah, which is the divine Law. Furthermore, his power is moderated by two types of advisers: the Sanhedrin and the courts (batey dyn). Thus, Abravanel sees the regime proposed by the Torah as a mixed system. Furthermore, 
establishing a monarchy is not seen as a mitzwah - a positive commandment—but simply as a possibility.

Abravanel wrote the commentary to Exodus when he was in Venice, acting as advisor to the Republic of San Marco. In the various Councils of the Republic among which power was distributed he identifies the intermediary bodies that Yitro recommended to Moses to alleviate the weight of justice. ${ }^{18}$ But this distribution, which for various authors represented the key to the solidity of the Venetian regime, is barely mentioned by the Jewish commentator. It is true that, with his citation, Abravanel implicitly attributes to Venetian institutions conformity with divine Law, but his citation is quick and scant - far from the genre of the direct apology.

In comparison, entirely and explicitly apologetic is the brief writing of another important author, David de' Pomi (Spoleto 1525-Venice 1593), who lived in central Italy - essentially in Umbria - and then moved to Venice. ${ }^{19}$ De Pomi, a member of a prestigious Italian Jewish family, was a well-regarded physician. As a writer, he intended nearly all of his work to familiarize Christian readers with aspects of Jewish culture, both biblical and rabbinic - we might speak of "civilization" - including showing them its moral elevation and closeness to Christianity. We are dealing, in his case, with work both informative and apologetic.

A brief piece in Italian by De Pomi, written between 1577 and 1587, 20 is political in character: Breve discorso nel quale si mostra la maestà divina haver particolar cura e custodia della repubblica Venetiana e che li oderni dì essa sono nel pubblico governo alle divine Mosaice constitutioni conformi (Brief discourse showing divine majesty having special care and protection of the Venetian Republic whose public governance is now in compliance with the divine Mosaic Constitutions). As indicated in the title, De Pomi wants to demonstrate that the Venetian Republic is constituted according to divine rule and that - as Abravanel wrote - its institutions, and in particular its advisors, corresponded to the Mosaic model. Furthermore, returning to one of his previous writings, De Pomi interprets some biblical passages (Isaiah 27:1-3 and Daniel 11:21-30) as prophesies of a Venetian victory over the Turkish fleet at the Battle of Lepanto and in subsequent years.

De Pomi not only uses a more explicitly laudatory tone toward Venice than Abravanel does, he also focuses on the ancient administration of justice according to Jewish rules — not only biblical, but also rabbinic: the monarchic 
institution, the Sanhedrin, and the much smaller courts. ${ }^{21}$ His many citations from the Mishneh Torah, the fundamental legal code of Maimonides, which was virtually unknown to the Christian public at that time, are characteristic of his work: De Pomi uses a text lauding the Republic of Venice to transmit some knowledge about Jewish civilization. Praising the Venetian constitution, he also indirectly lauds rabbinical law, which conforms to that constitution.

His designation of a mixed government as ideal, and the limits that he demonstrates are imposed on the power of the king, who must strictly comply with the rule of the Torah, show that De Pomi, like Abravanel before him, had a clear anti-monarchical orientation. He believed that Jewish decadence derived from the lack of respect for biblical and rabbinic institutions:

While this order was observed, the Jews happily dominated, but as the rules and laws started to be broken, their dominion began to decline, such that finally, because of our sins, the masters became the servants of all..$^{22}$

De Pomi suggests that the Jews' condition of weakness and servitude has a political-religious origin, which implicitly means that it does not result from the sin of not recognizing Jesus as Messiah, as argued by Christian theologians. This idea is confirmed in the trilingual Dittionario De Pomi wrote, where, in the definition of the word "king," he noted that the contemporary Jewish condition is the product of a lack of respect for the rules of the Torah with regard to the limits of monarchical power. Wanting to be "like all other peoples," and thus not recognizing the divine origins of their political and military successes, the Jews lost all of their strength. In other words, God left them because they did not recognize their special election, and not because - as Christian theology maintained - they did not accept that their special election had been transferred to the universal community of believers in Jesus:

Our fathers gained all their marvelous victories not through multitudes of people, nor the horses they purchased, but only through the infinitely triumphant divine power. When, therefore, they started to ally now with one, now with the other lord with earthly power, heaven started to turn its back on our princes, along with the people, and still we bear the penalty. ${ }^{23}$ 


\section{Simḥa Luzzatto's Apologia}

\section{as a Pattern of Universal Political Thought}

Simone Luzzatto (1583-1663) represents a third form of Jewish intellectual self-positioning in relation to politics. ${ }^{24}$ Luzzatto was Rosh Yeshyvah of the Venetian Jewish community-i.e. its leading rabbinical authority-at a time when it was one of the most prestigious Jewish communities in the world, while also being a meeting point for Jews from Northern Africa, the Ottoman Empire, and Northern Europe.

It is worth emphasizing that Luzzatto's most ambitious books-Discorso circa il stato de gl'hebrei and Socrate, ovvero dell'humano sapere ${ }^{25}$-were written in Italian: in other words, he chose to address the intellectual community at large, irrespective of religious differences. This open-minded stance contrasted with the ethnically and religiously exclusivist tendencies of contemporary Jewish Italian culture, which had led to a refusal to resort to any language other than Hebrew. Moreover, the popularity of theological and kabbalistic approaches had taken politics off the Jewish agenda. Luzzatto was perfectly aware of this, and on various occasions he brought attention to the pernicious widening of the gap which separated Jewish culture from the sciences. ${ }^{26}$

Published in Venice in 1638, Luzzatto's Discorso circa il stato de $\mathrm{gl}$ 'hebrei is an essay on the continued existence of the Jewish people in a big city, namely Venice. Demonstrating its author's understanding of political economy, this brilliant book describes the social identity, economic activities, and intellectual concerns of the Jewish community. This aspect of Luzzatto's work is strikingly realistic, and totally devoid of the exalted idealization which characterizes Portaleone's account of the Jews. Luzzatto's assertion that one would be hard pressed to define Jewish customs, exemplifies his position. Following a general introduction on the contradictions and paradoxes of the human soul and manmade society - by way of Anaxagoras, Plato, and Solomon, together with a few examples taken from Roman history-Luzzatto explains:

If [...] it is difficult to define the particular customs of an individual, how can one determine those of an entire Nation? [...] The soul of their Nation is so debased and weakened as to be incapable of any form of political governance while they are in their current state. So preoccupied are they with their particular predicament that they fail to take any interest in the 
universal and are parsimonious to the point of meanness. They are great admirers of ancient times but poor observers of current affairs [...] Whatever their faults may be, they nevertheless also exhibit many noteworthy qualities. They are steady and wonderfully unwavering in their belief in, and observance of, their Religion. [...] They are admirably constant—if not always in the presence of danger, then at least in the face of adversity.

The Jews are thus described as being devoid of any interest in the universal and incapable of political organization. In the context of Luzzatto's essay, these characteristics were to the advantage of the States which had taken them in, insofar as a scattered people with neither leaders nor political ambition would not pose a threat to their local institutions.

We saw Alemanno grant political qualities reflecting the ideal virtues of King Solomon to a contemporary city and person from outside the Jewish sphere, while Portaleone tried to integrate the political, social, and military realities of his time to the Jewish experience. Luzzatto adopts the perspective of an outsider, in a bid to avoid disguising the moral and political weaknesses of his co-religionists. His concern for realism is genuine, and he does not let Portaleone's national mysticism water it down. Wishing to elaborate upon a political theory of universal import, as his Socrate makes clear, he reflects on several questions and texts from outside the Jewish tradition. In that respect, his Discorso circa il stato degl'ebrei anticipates the completely objective perspective which Spinoza claimed to adopt in his Tractatus theologicopoliticus thirty-two years later. Yet, whereas the Dutch philosopher sided with Reason and aspired to rid himself of religious dogmas and partial visions, the Jewish Luzzatto could not be so independent: instead, he couched his observations in the partisan genre of the Apologia.

In an important article about Simone Luzzatto, ${ }^{27}$ Abraham Melamed shows that the Venetian rabbi reviews Tacitus' indictment of the Jews not only in order to dismiss the charges leveled at them by a number of contemporary Christian authors, ${ }^{28}$ but also in order to hint at his Machiavellian vision of history and politics. As Luzzatto could not openly mention an author as subversive as Machiavelli, he

like many other Italian thinkers of the period, solved his problem by turning to classical sources. When it was too dangerous to quote Machiavelli, he turned to Tacitus. ${ }^{29}$ 
But the Venetian rabbi is forced to resort to a more convoluted subterfuge than non-Jewish authors by integrating his general, "universal," ideas in an Apologia. Even as they articulate a defense of the Jews and Judaism, the arguments Luzzatto develops in his Discorso have more far-reaching implications. In other words, as a member of the minority under discussion, Luzzatto make the particular case of the Jews the focus of his universal thought.

This leads him to find surprising rationales for the most hermetic religious rites by ascribing political motivations to them. Thus, commenting on the ban on pork, Luzzatto quotes a passage from a classical author in order to introduce Machiavelli's notion that religion is an instrumentum regni: the most absurd rites, he writes, help monarchs to bend the minds of their subjects and test the limits of their obedience. ${ }^{30}$ Nevertheless, he covers himself by adding that "God's decrees exceed the scope of our investigations and defy human understanding." " ${ }^{11}$ Dismissing the charge of superstition Tacitus leveled at the Jews, Luzzatto declares - still quoting the Classics ${ }^{32}$ - that although superstition helps rulers to assert their power, it can be very harmful if it takes over their own minds. He develops this idea in an interesting comparison:

The world is akin to a big market; God apportions riches between us so we may purchase what is on display and for sale. The most widespread among these riches are prudence and strength, and they bear God's seal because He is science and strength. With these riches, we can cope with everything that depends on the will of man. Real religion belongs to those who ask God for this abundance of wealth (pecunia). ${ }^{33}$

As well as obviously referring to Machiavelli- prudence and strength are the Prince's virtues ${ }^{34}$ — this passage glorifies and consecrates capitalism and the market society with religious language. ${ }^{35}$

Throughout his essay, Luzzatto develops a political theory based on the observation of actual facts and the rejection of the principle of authority. ${ }^{36}$ At a time when Italian society is still dynamic and thriving, despite worrying signs of early decadence, he privileges active lives over contemplative existences, and realistic policies over utopias. ${ }^{37}$

Although his perspective is mystical and visionary, Portaleone shares this stance. The realistic point of view which these authors privilege leads them to turn away from theology when interpreting reality, and to give up on both the notion that the Jews are intrinsically different-as is preached by the 
kabbalists - and the idea that the people of Israel are chosen. Whether what spurs them on is the logic of scientific discourse - as in Portaleone's case- or Machiavelli's empirical approach to history - as in Luzzatto's - these Italian Jewish thinkers cannot conceive of the election of the people of Israel as formulated by Sephardic philosophers such as Yitzhaq Abravanel, Menasseh ben Israel, or Yitzhaq Cardoso. These Sephardic Jews shared in the Christian notion of the singularity of the Jewish people - whether God had chosen or cursed it — and had absorbed the Spanish notion of pure blood, ${ }^{38}$ applying it to the Jewish people in a process which evokes René Girard's "antagonistic mimesis." ${ }^{39}$

In contrast, even deeply pious thinkers such as Portaleone conceived of the Jewish nation independently of theological concerns, as a nation which ought to be on an equal footing with others and need not be considered superior. Indeed, as Spinoza remarks at the opening of his Tractatus theologicopoliticus,${ }^{40}$ only the imagination - as opposed to an accurate perception of factual reality - can validate the notion that one nation is intrinsically superior to others. 